\title{
EUlOGio NishiYAMA: Fotógrafo DEL CUSCO
}

Nada más fidedigno que el lenguaje fotográfico en su intención de testimoniar la vida y los eventos humanos. Esta certeza se evidencia más cuando apreciamos el arte de Eulogio Nishiyama Gonzales (Cusco, 1920-1996), fotógrafo de ascendencia japonesa y testigo privilegiado de una época remecida por notables acontecimientos. Sin el registro de su cámara, quizás quedaría incompleta la narrativa histórica del Cusco correspondiente al siglo XX, tal vez sumergidos algunos sucesos que determinaron los cambios sociales y la decidida incursión en la modernidad. Gracias a este artista, resulta más amplio el panorama que podemos visualizar de nuestro pasado reciente, especialmente de su rica diversidad social y cultural.

Será que para el lente de Nishiyama nada de lo humano le era ajeno, según el decir del inspirado comediógrafo latino. Todo cuanto de destacable ocurría en la ciudad y la región, él lo registraba con vocación de perennidad, acudiendo con espíritu abierto, bien sea al acontecimiento político trascendente como la llegada a Cusco de Eva Duarte de Perón, al suceso familiar consistente en una humilde boda de campesinos, a la concentración de jinetes en la plaza de Santo Tomás, o a la manifestación eucarística en la plaza de armas. En suma, dotado de visión coreográfica y sensibilidad de artista plástico, el fotógrafo estaba allí donde latía el fervor de la multitud, impulsado por su voluntad de cronista de la historia cotidiana y también documentalista de eventos de más estricta memoria, atributos que honrosamente lo acercan a la prosapia estética de Chambi y de Figueroa Aznar.

Artista de doble pericia instrumental, Eulogio Nishiyama además incursionó en la cinematografia, llegando a ser el pionero del documental etnográfico en nuestro medio. Aquí filmó, desde la década de 1940, una serie de eventos de la cultura tradicional cusqueña (tanto rural como urbana), quizás bajo el influjo del discurso indigenista en boga, pero esencialmente motivado por sus arraigadas convicciones sociales. Son singulares sus documentales sobre la festividad de Quyllurit'i, el rito de Qhiswachaka, la tauromaquia chumbivilcana, el carnaval citadino de Cusco, y el concurso de belleza indígena, entre otros. En 1956 fue co-fundador del Cine Club Cusco, el cual, cinco años después, concretaría la primera película en lengua quechua: Kukuli, cuyo éxito hizo hablar al historiador francés George Sadoul sobre la existencia de la Escuela de Cine de Cusco.

Por todo ello, la Revista Universitaria presenta aquí una parte interesante del legado fotográfico de Eulogio Nishiyama y, al difundirla, cumple con revalorarlo como uno de nuestros más renombrados exponentes de las artes visuales. El recuperó las imágenes de un ayer cercano que todavía proyecta sus luces sobre la agenda social de este inicio de milenio. Su vasto testimonio gráfico bien puede ayudarnos a entender las claves interactivas que articulan el pasado con el presente, en perspectiva a diseñar las bases del futuro. (ERP) 


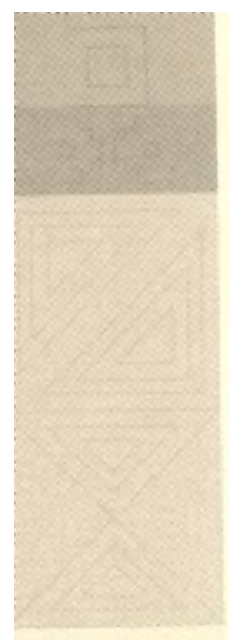

REVISTA UNIVERsTrARIA I4l

314

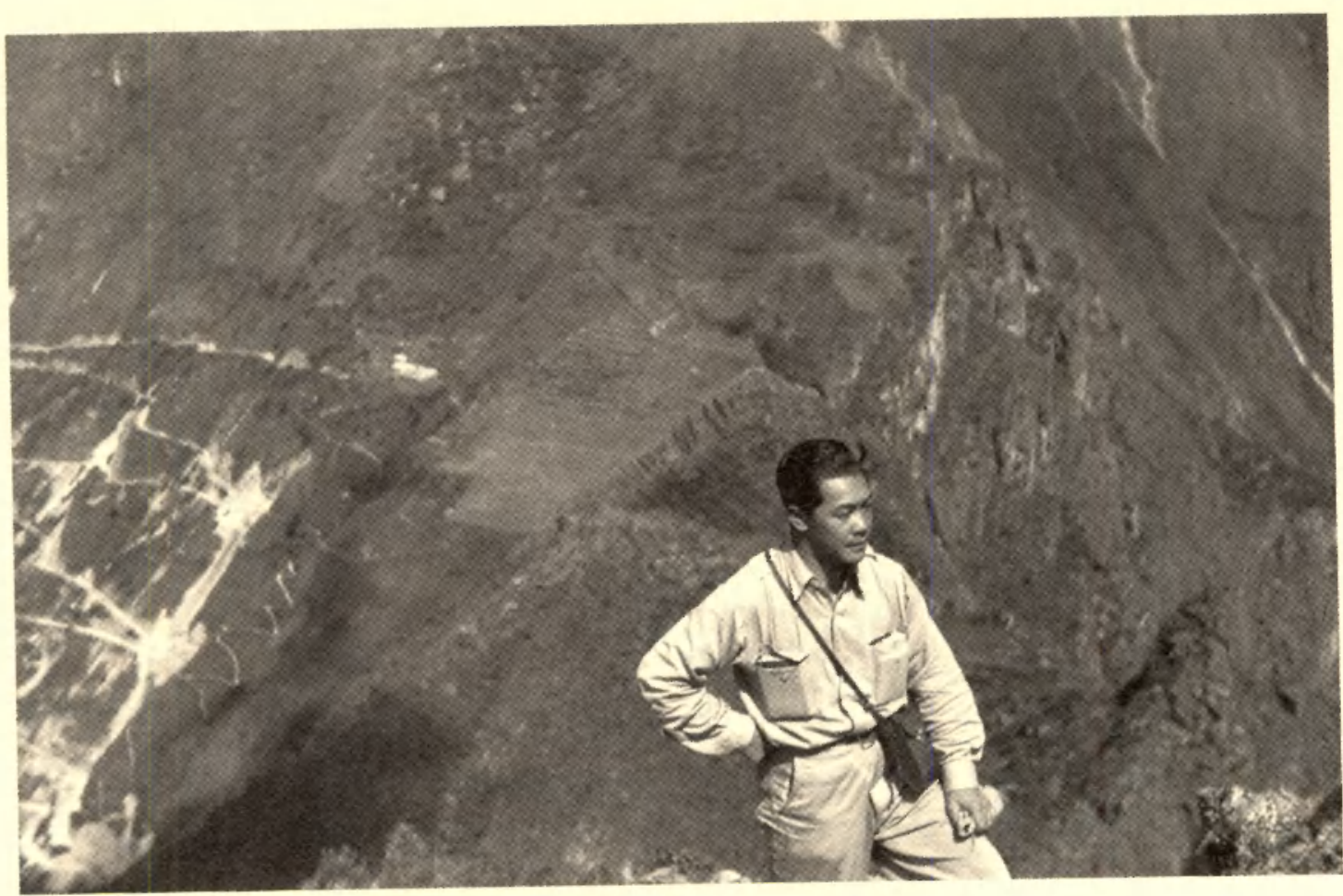

V Autossetrato.

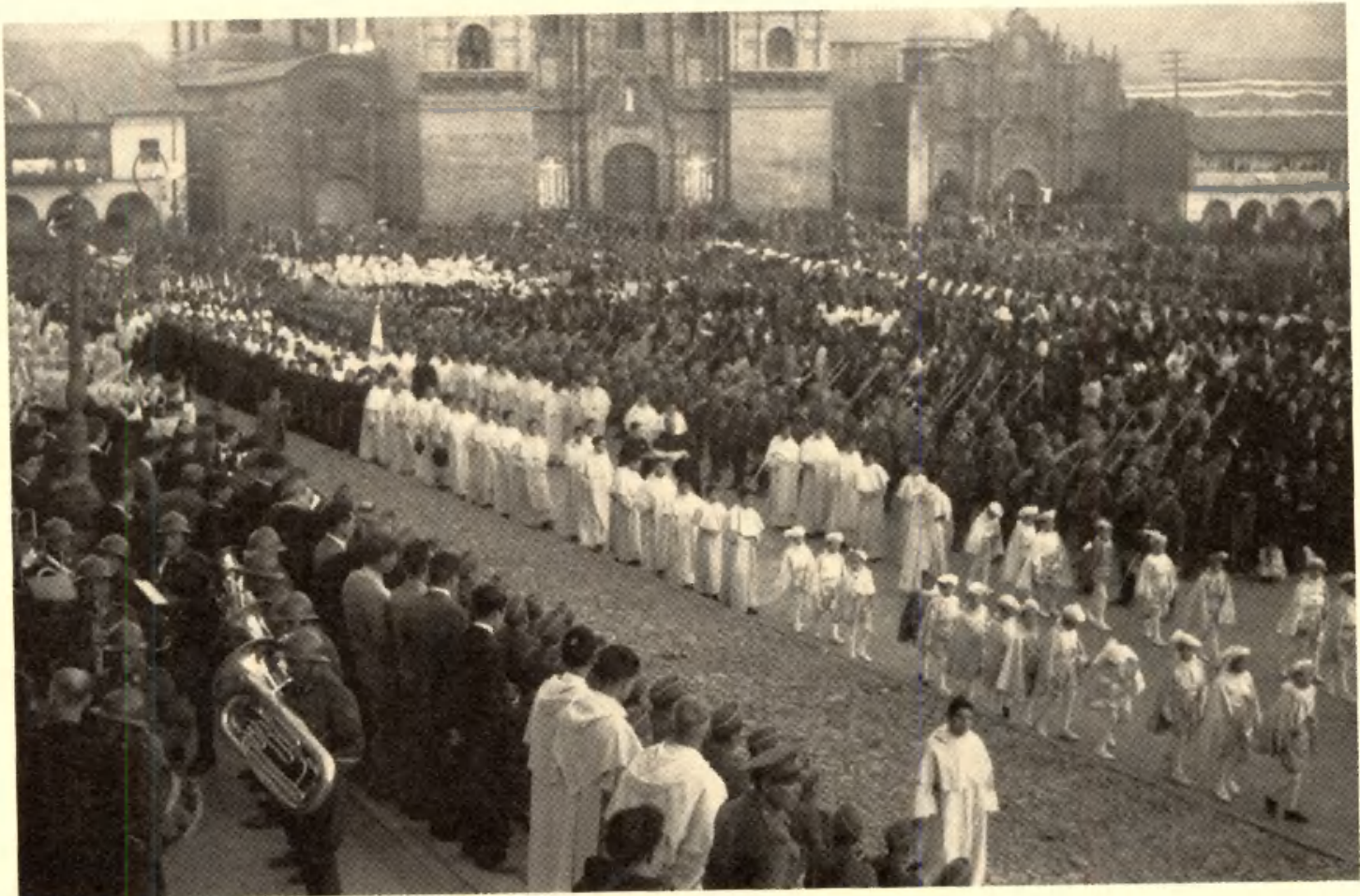

- Congreso Eutcaristico. 


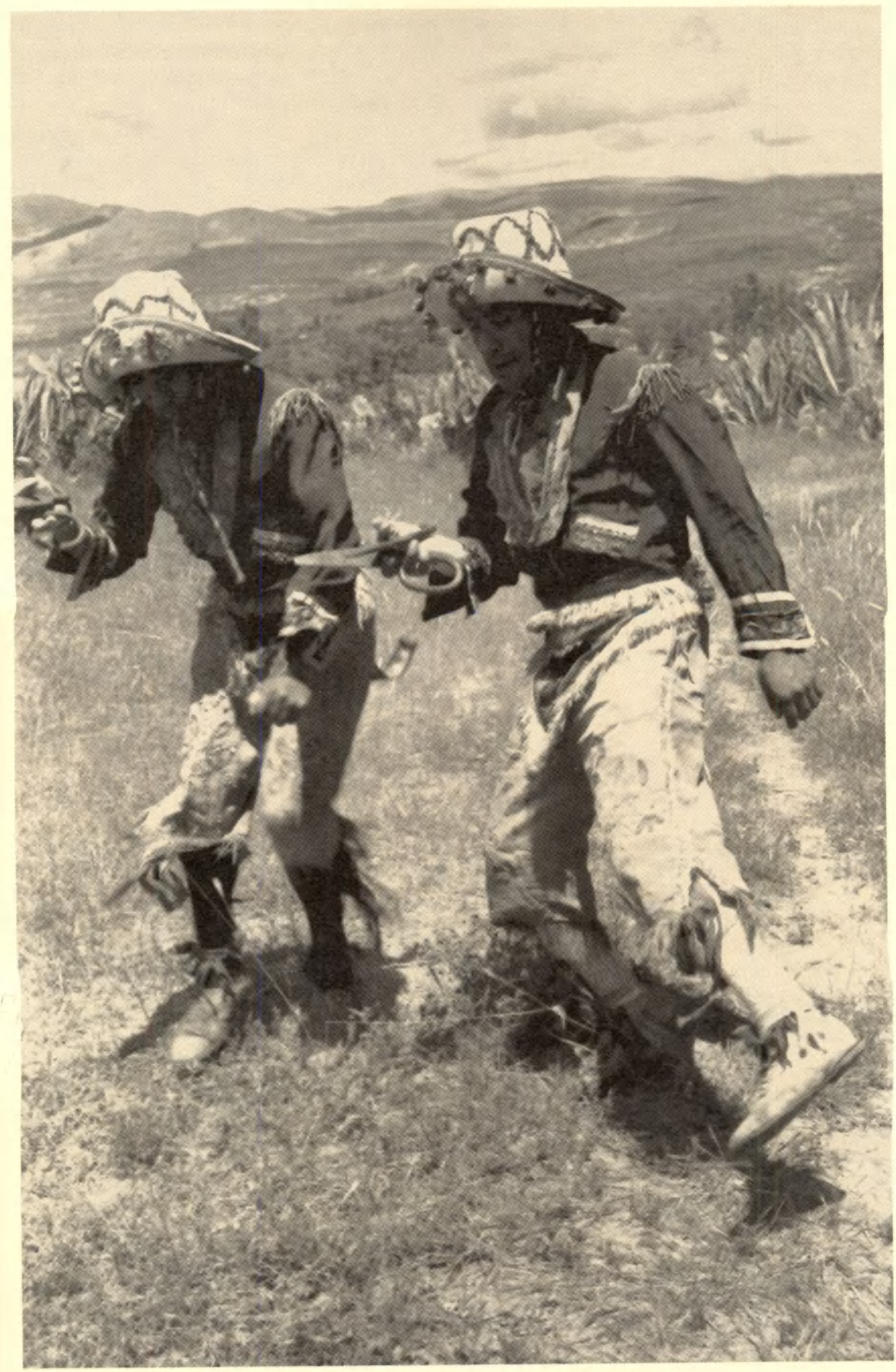




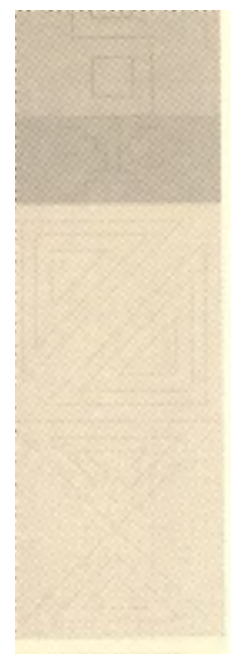

316

RENTSTA UNIVERSTTARIA 141

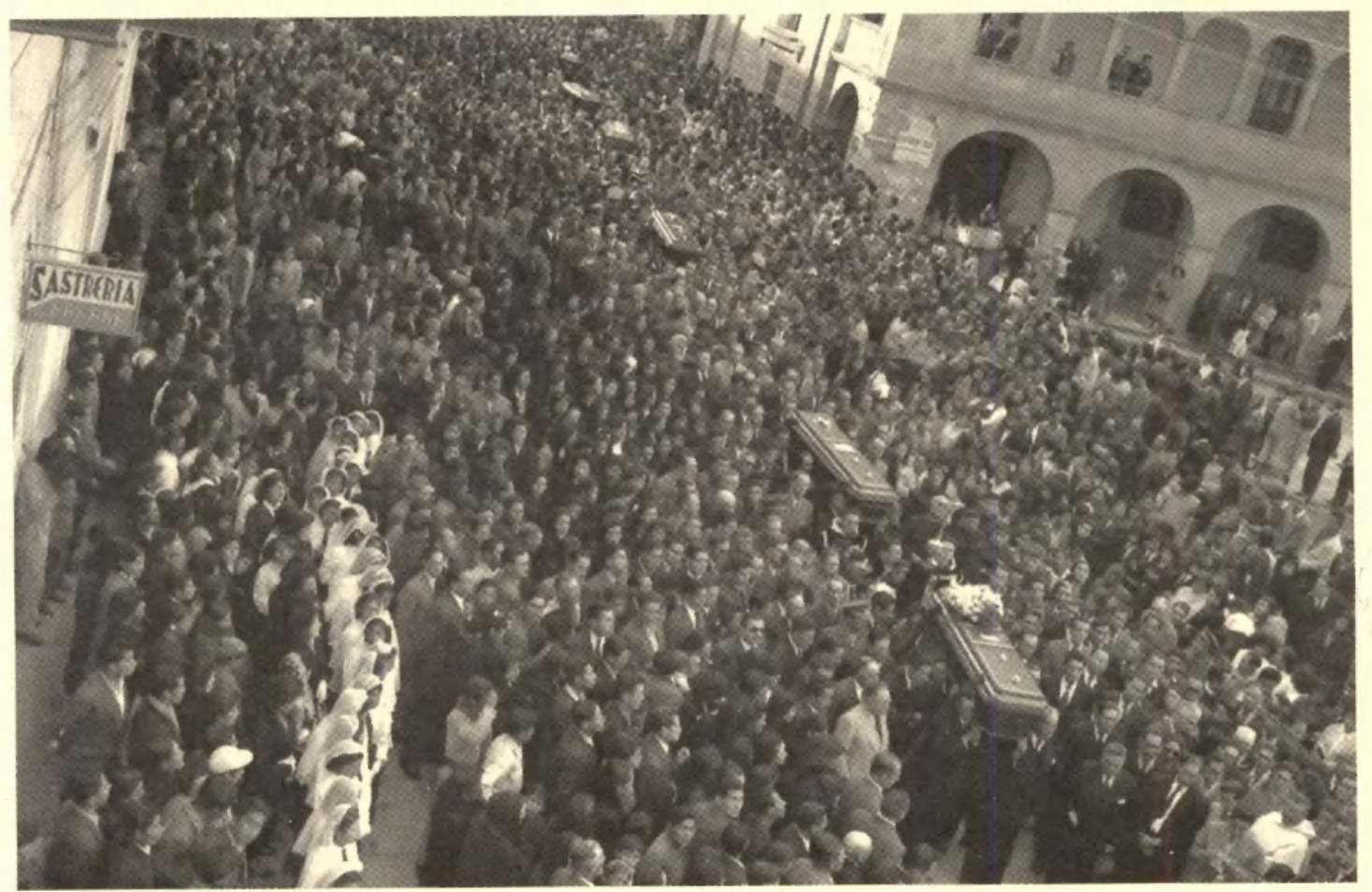

- Entierro de victimas de un accidente de aziación.

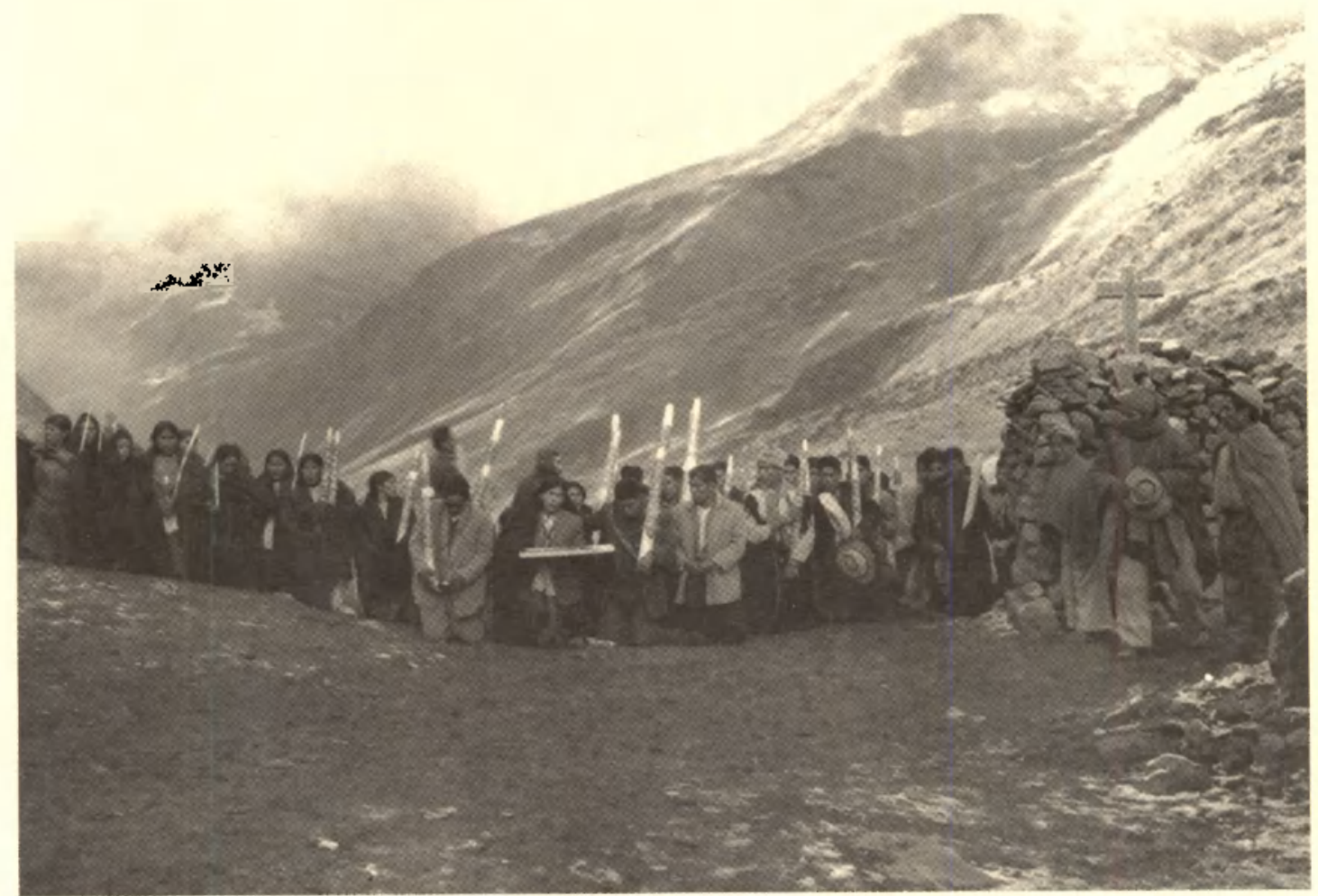

- Escena de Qutylut Riti. 
100 AÑOS

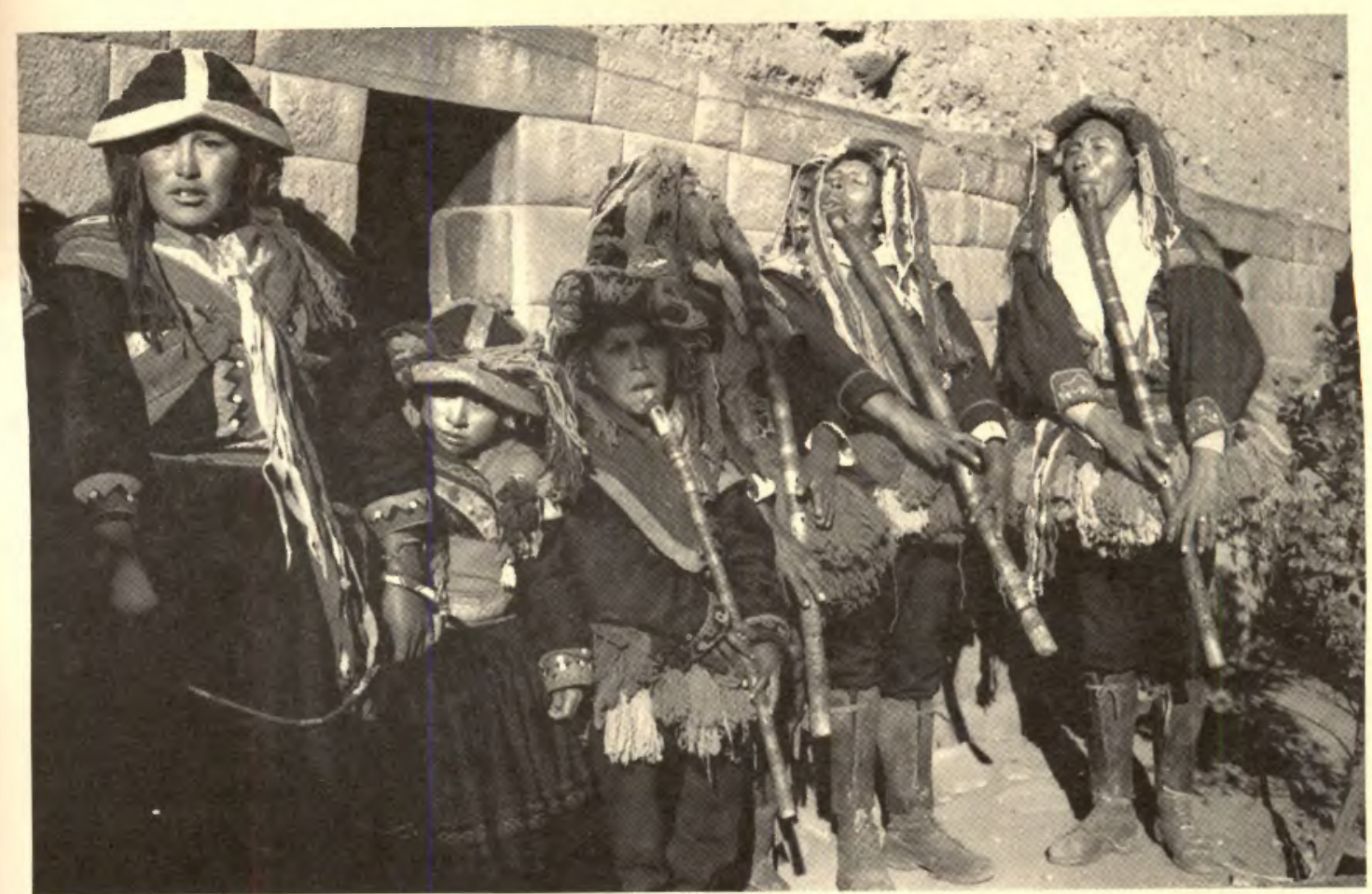

- Familia de Chucos con maro inca de fondo

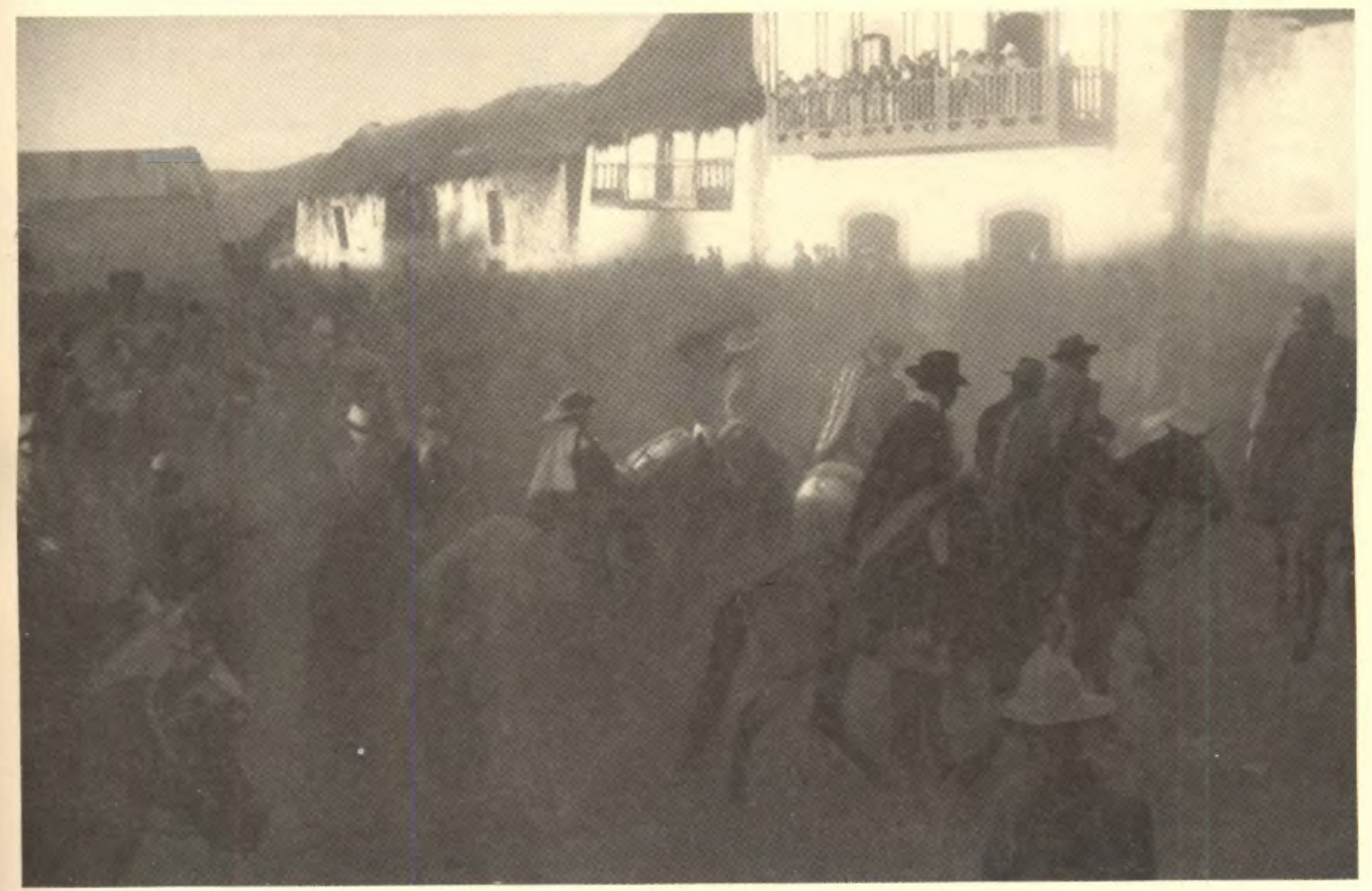

$\checkmark$ Gamonales entrando a Santo Tomás 


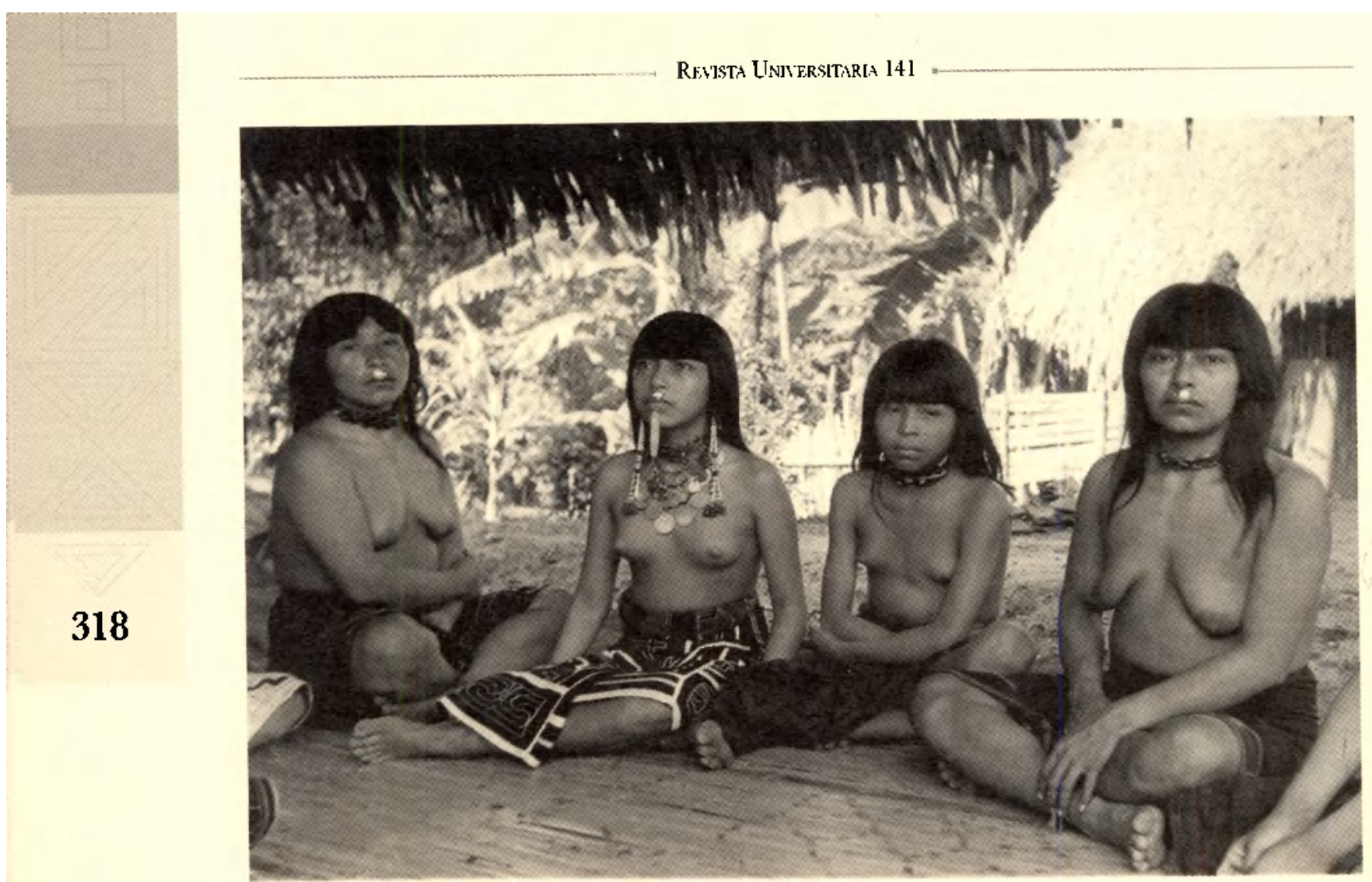

- Familia de mujer Shipiba.

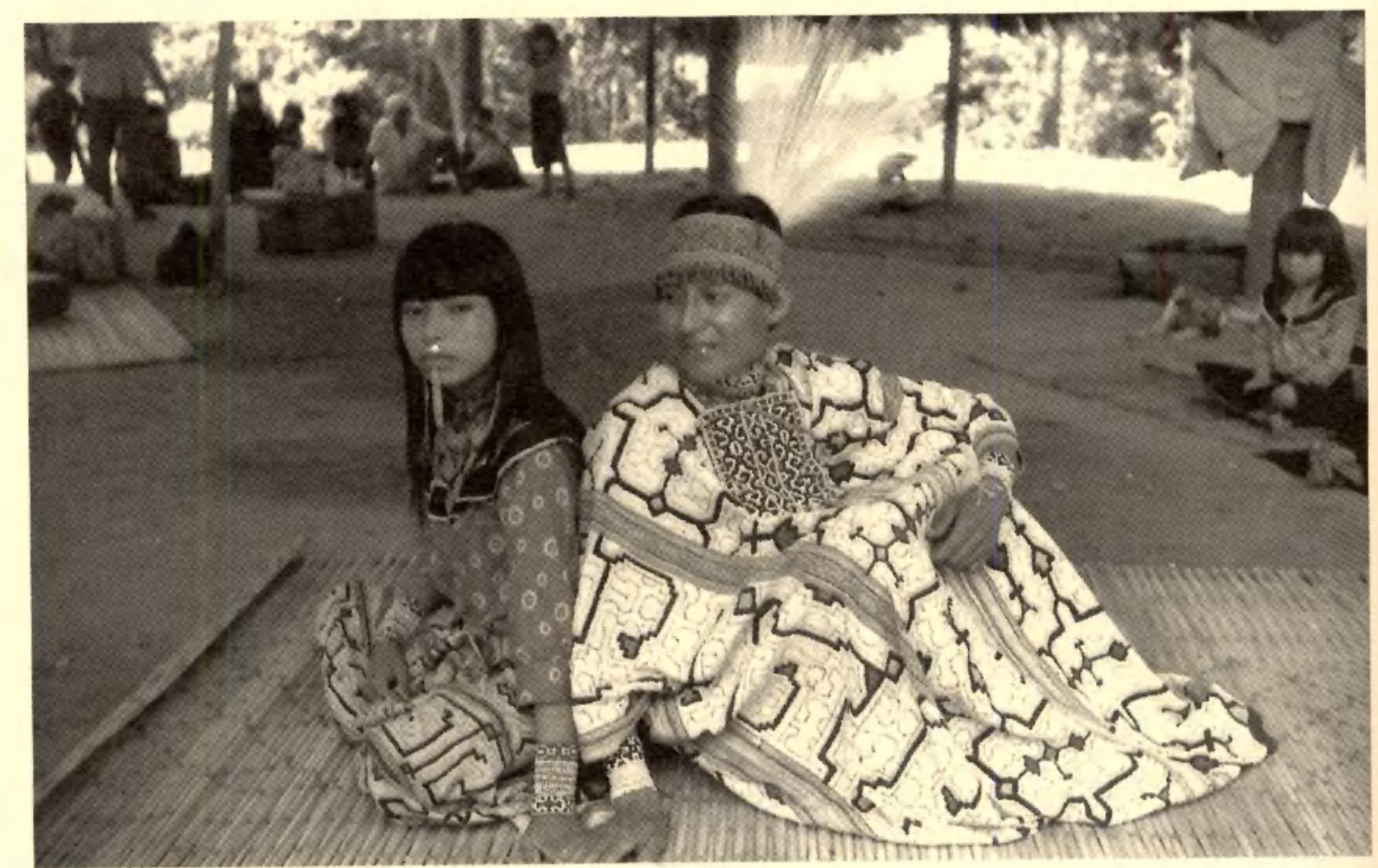




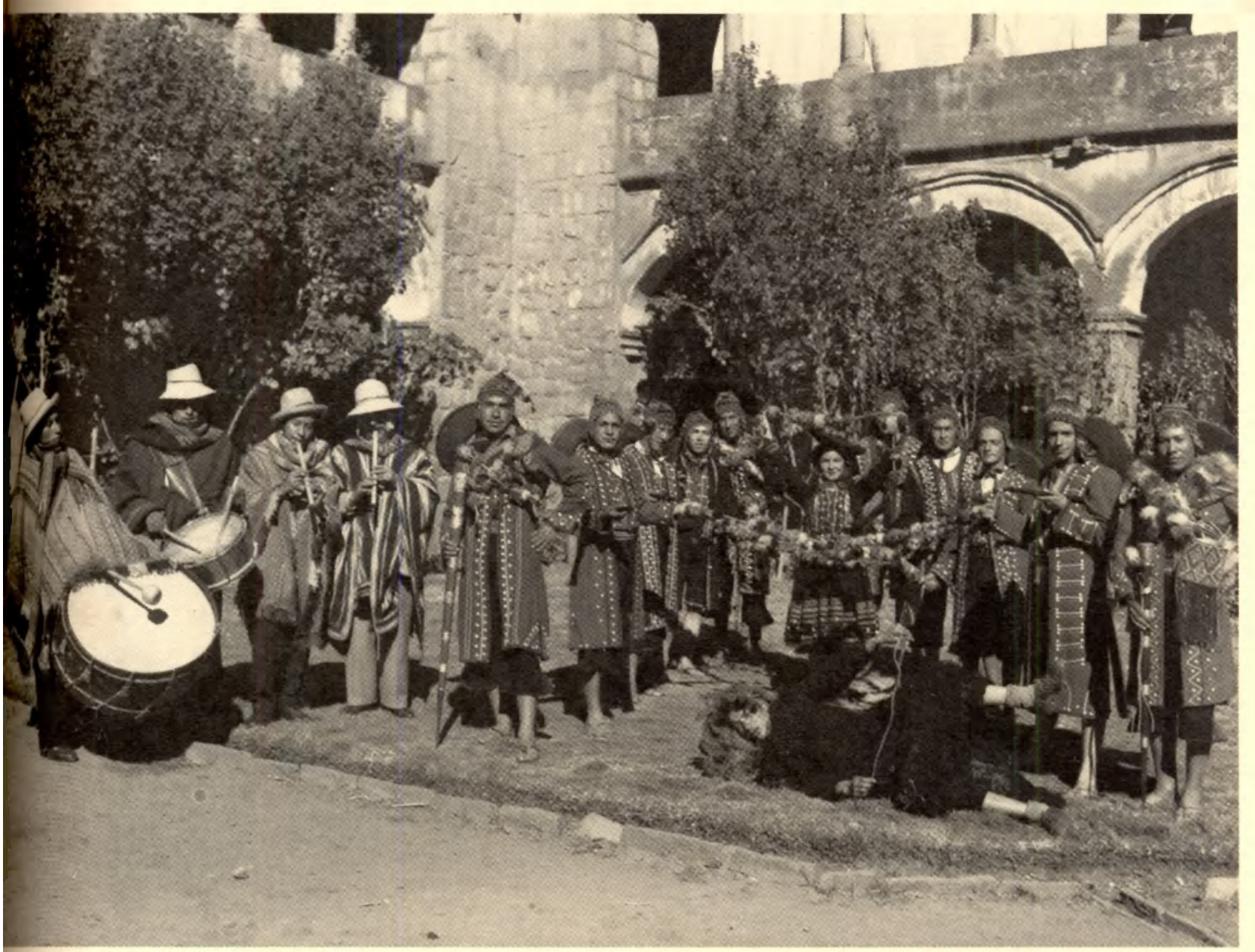

- Grupo artístico en patio colonial. 


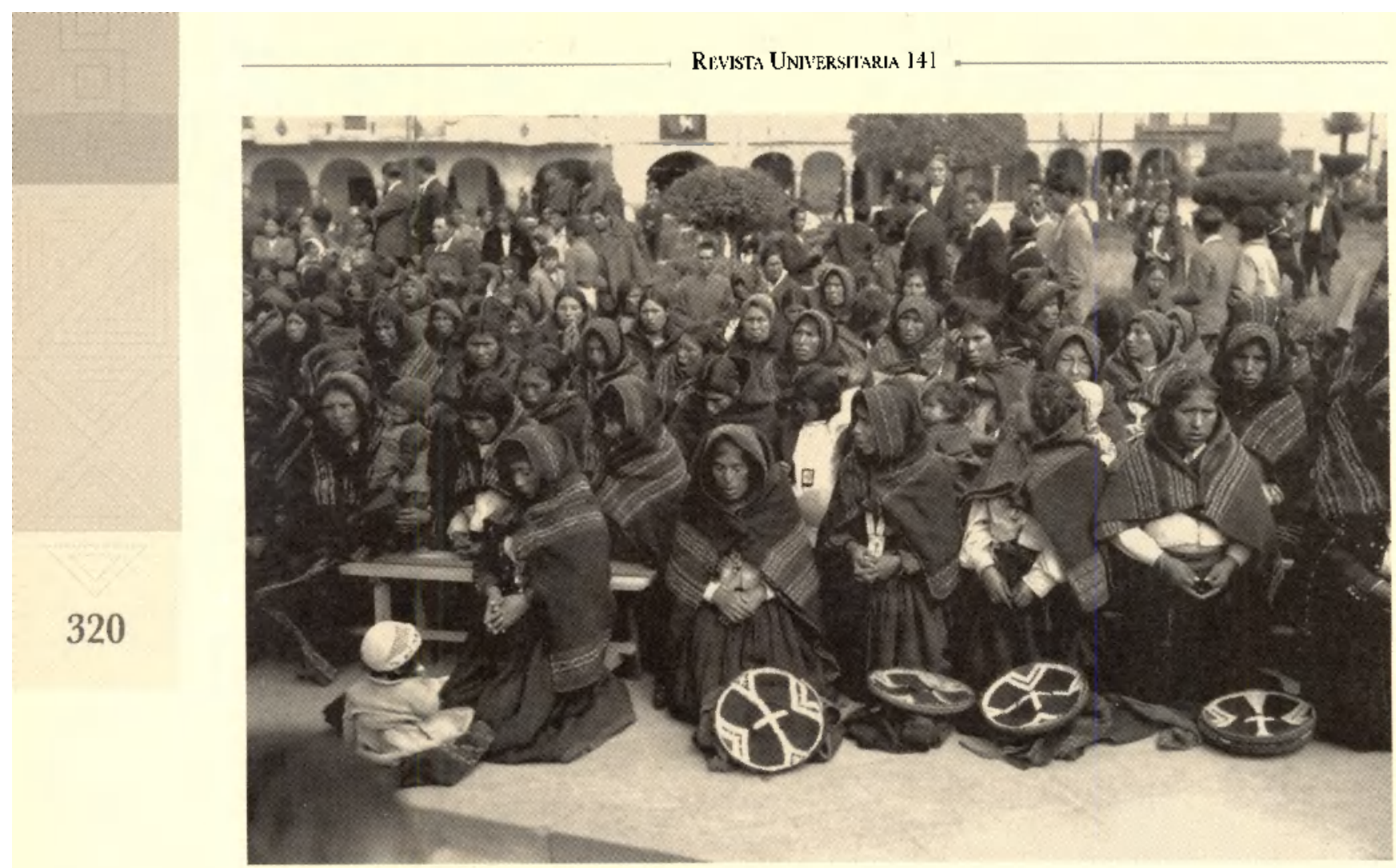

$\checkmark$ Laplegana.

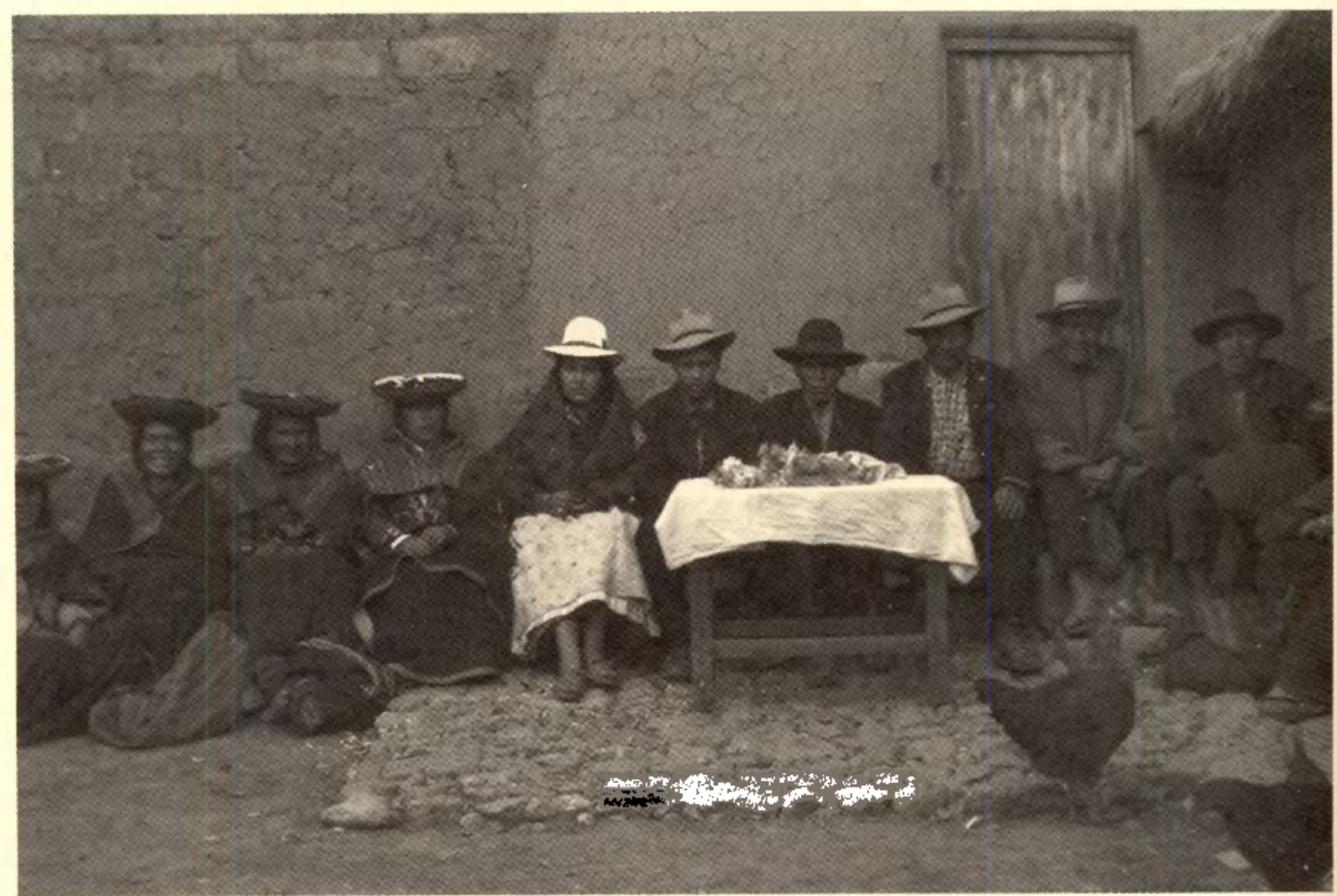




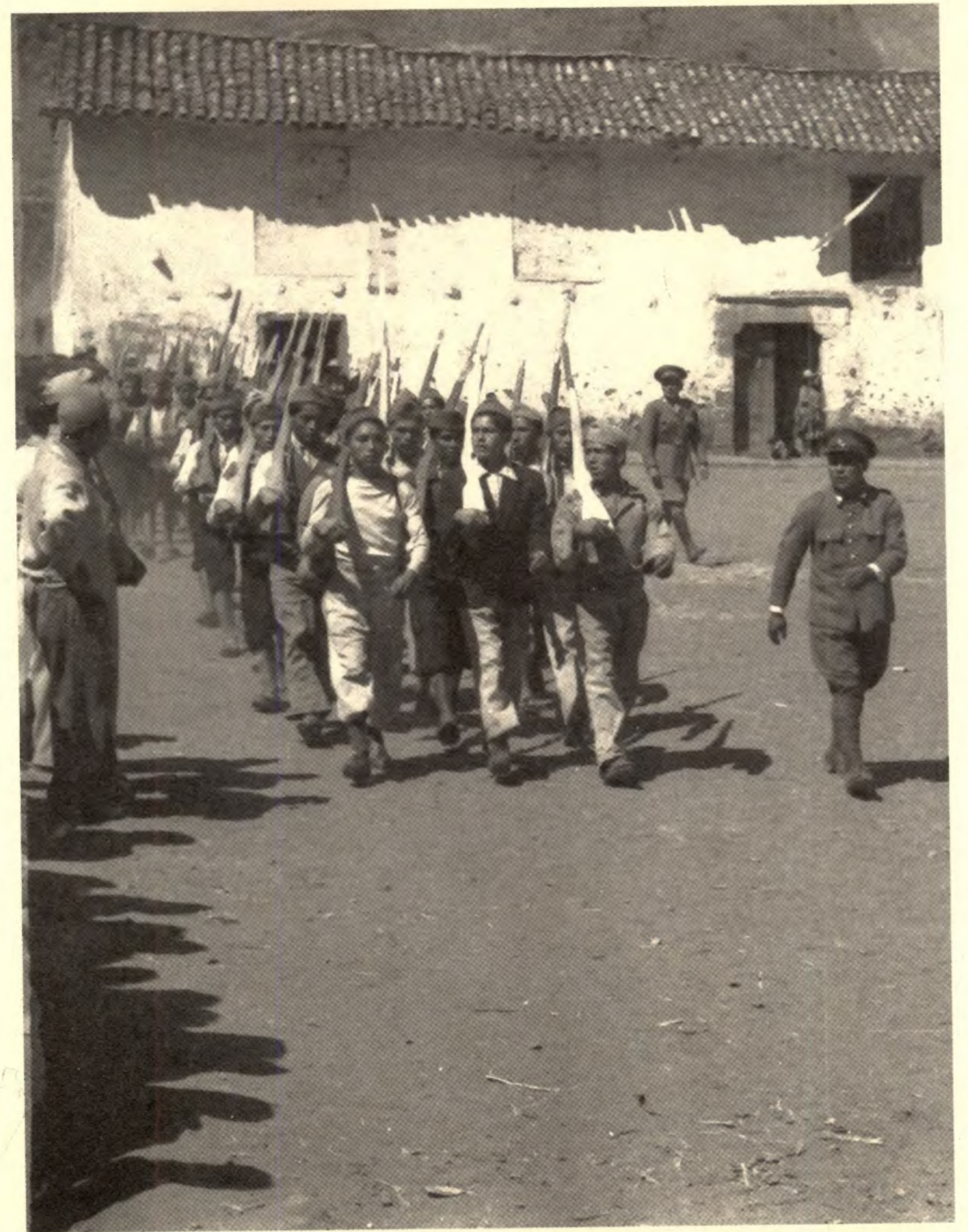

321

- Moolizables en Pisac. 


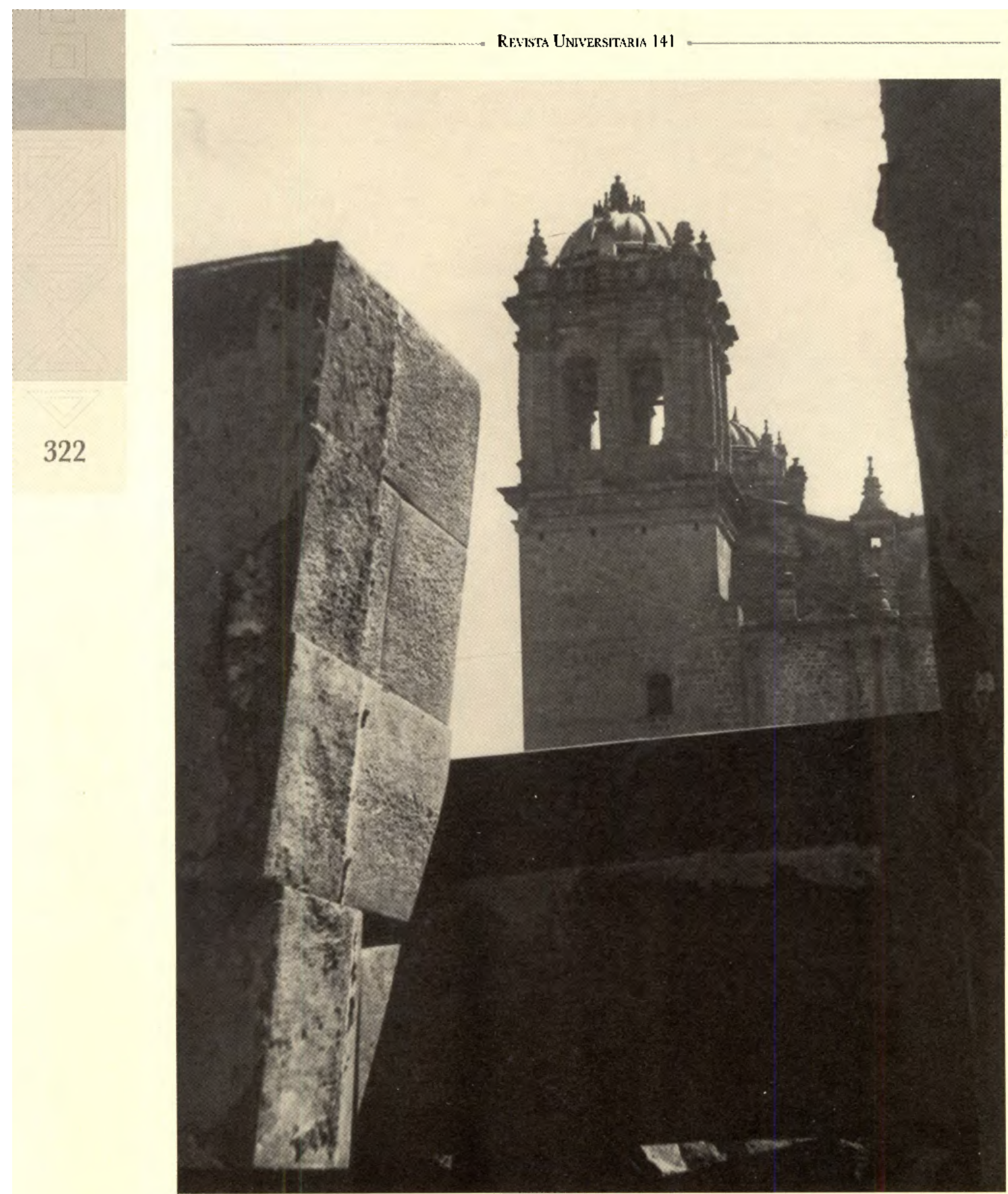

- Muro Inca con la Catedral al fondo. 


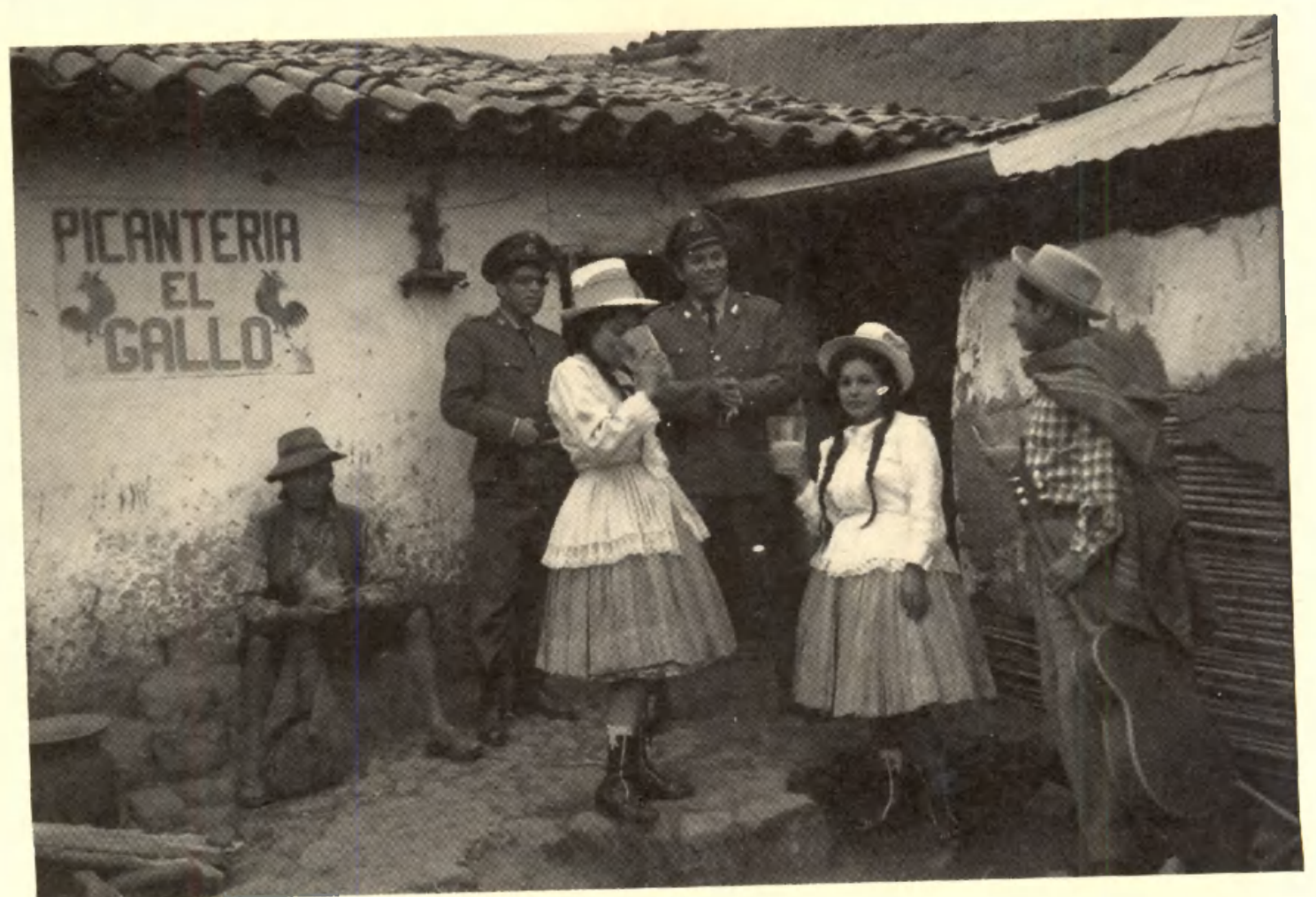

323

- Ptranterí El Gallo.

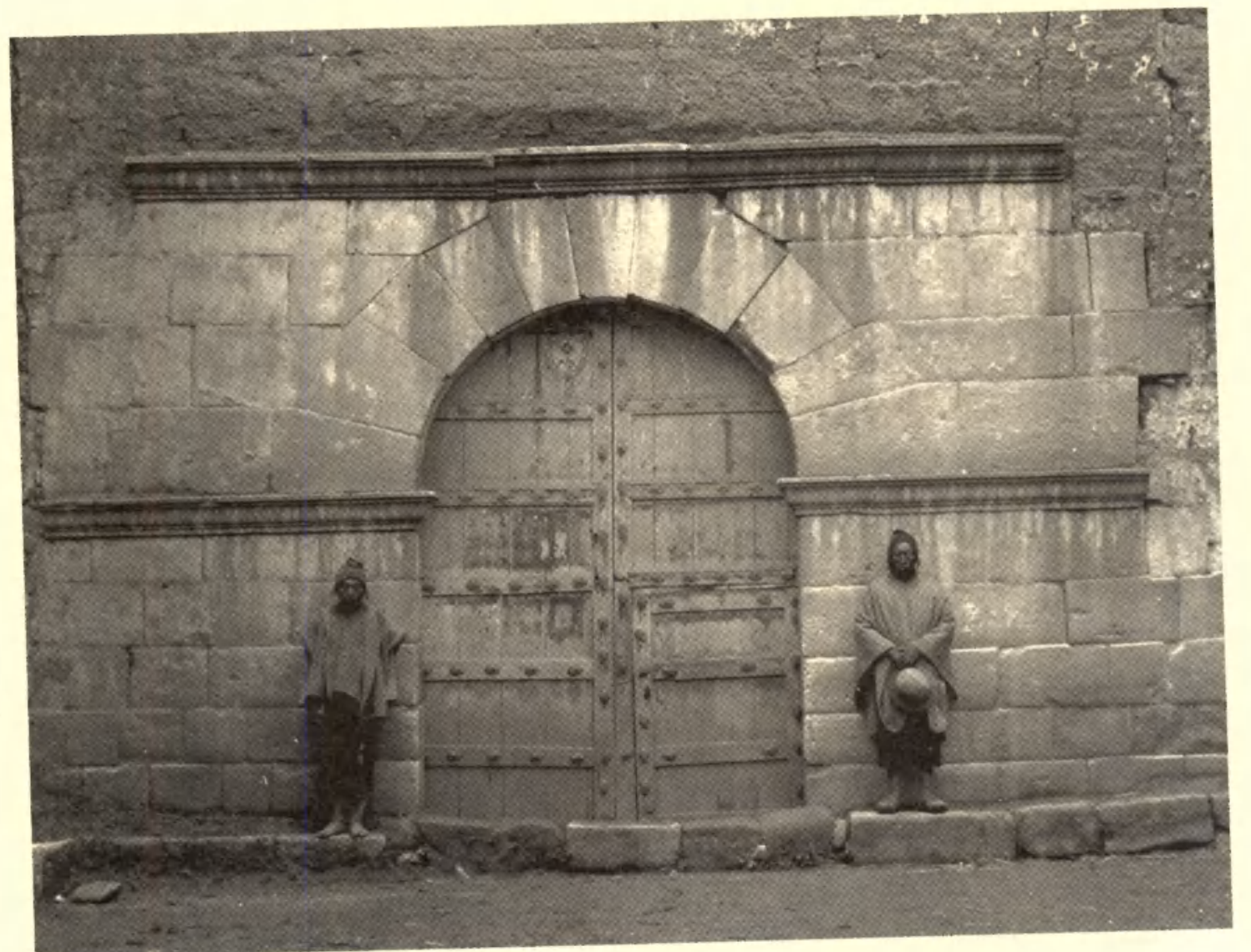




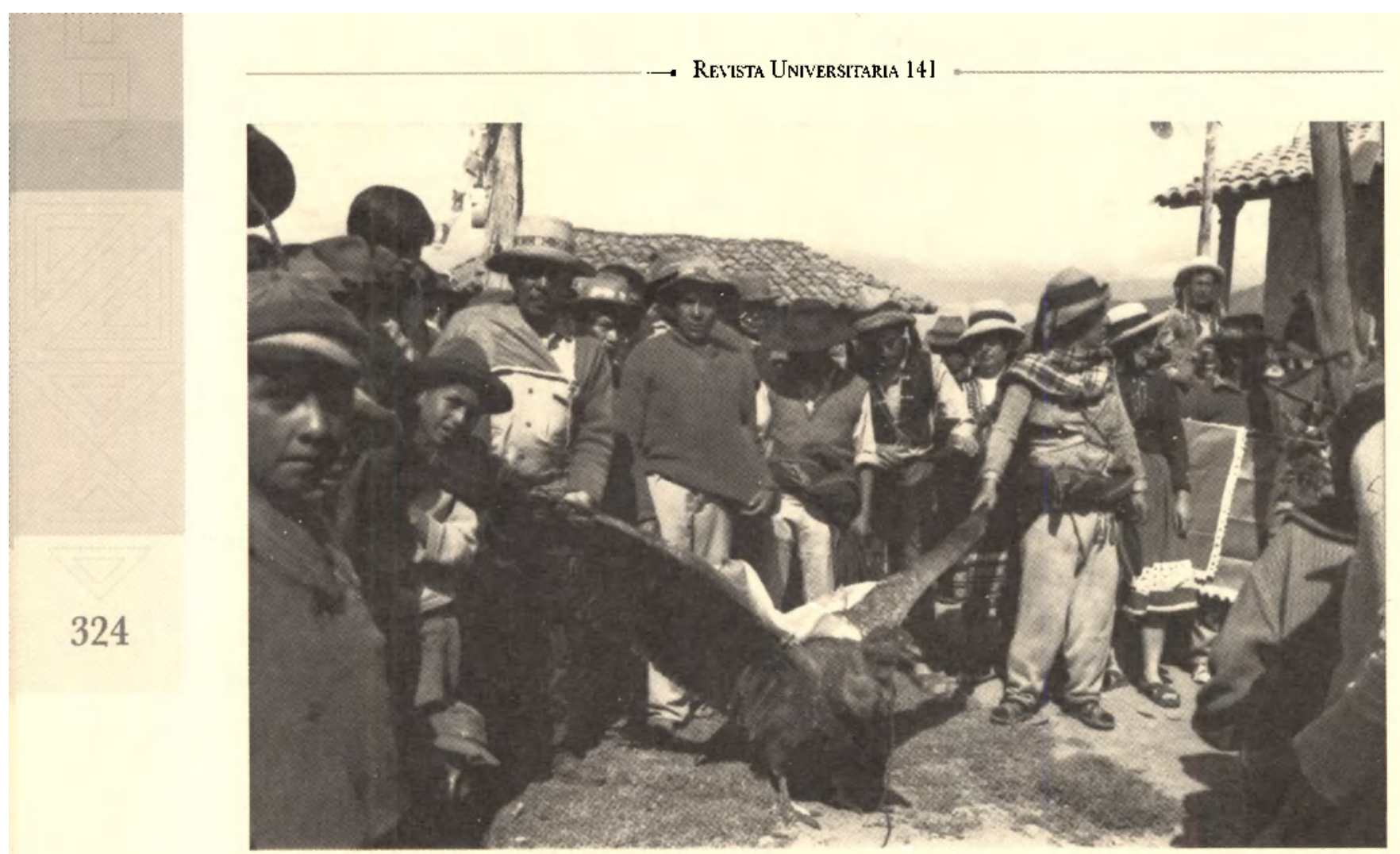

V Ritual del condor.

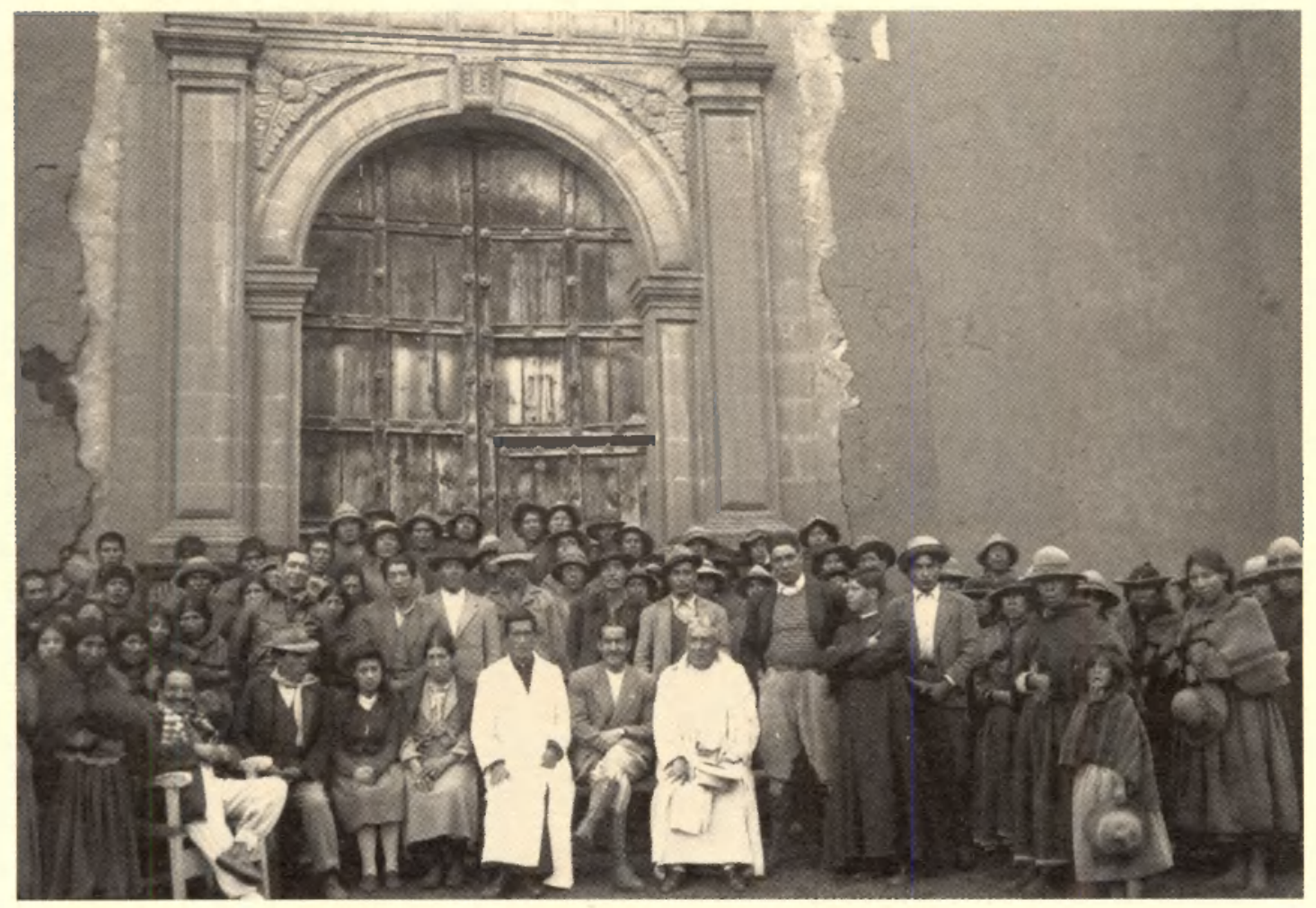

TSeñotes, mestizas e indias. 


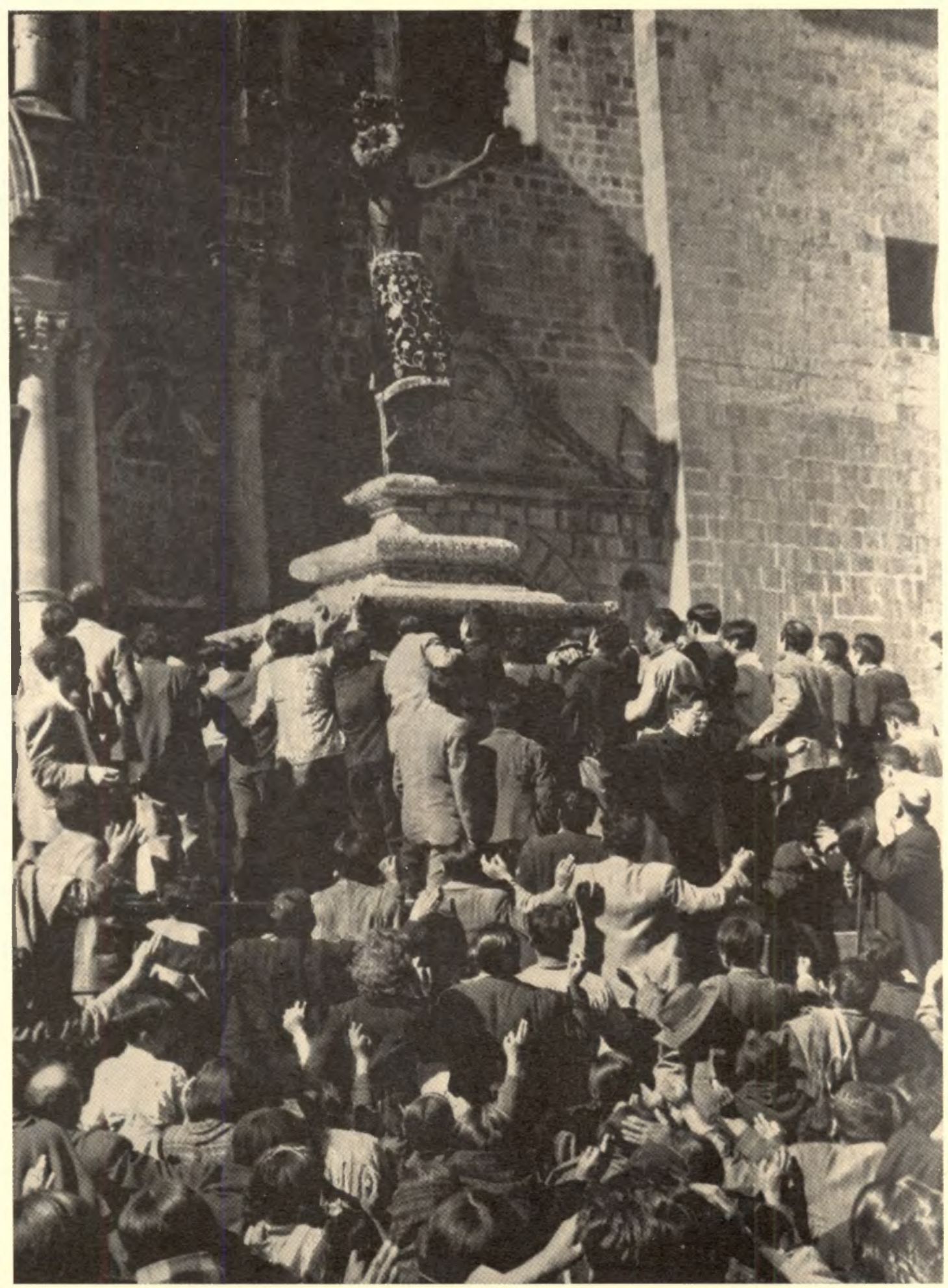




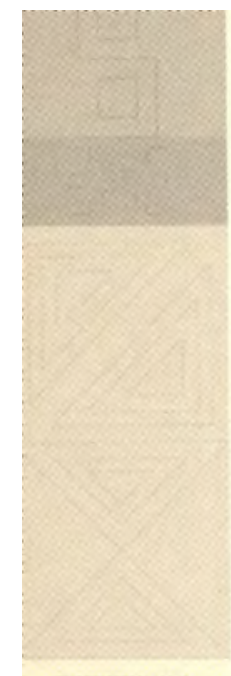

326

RevisTa UNIVERSTTARLA 141

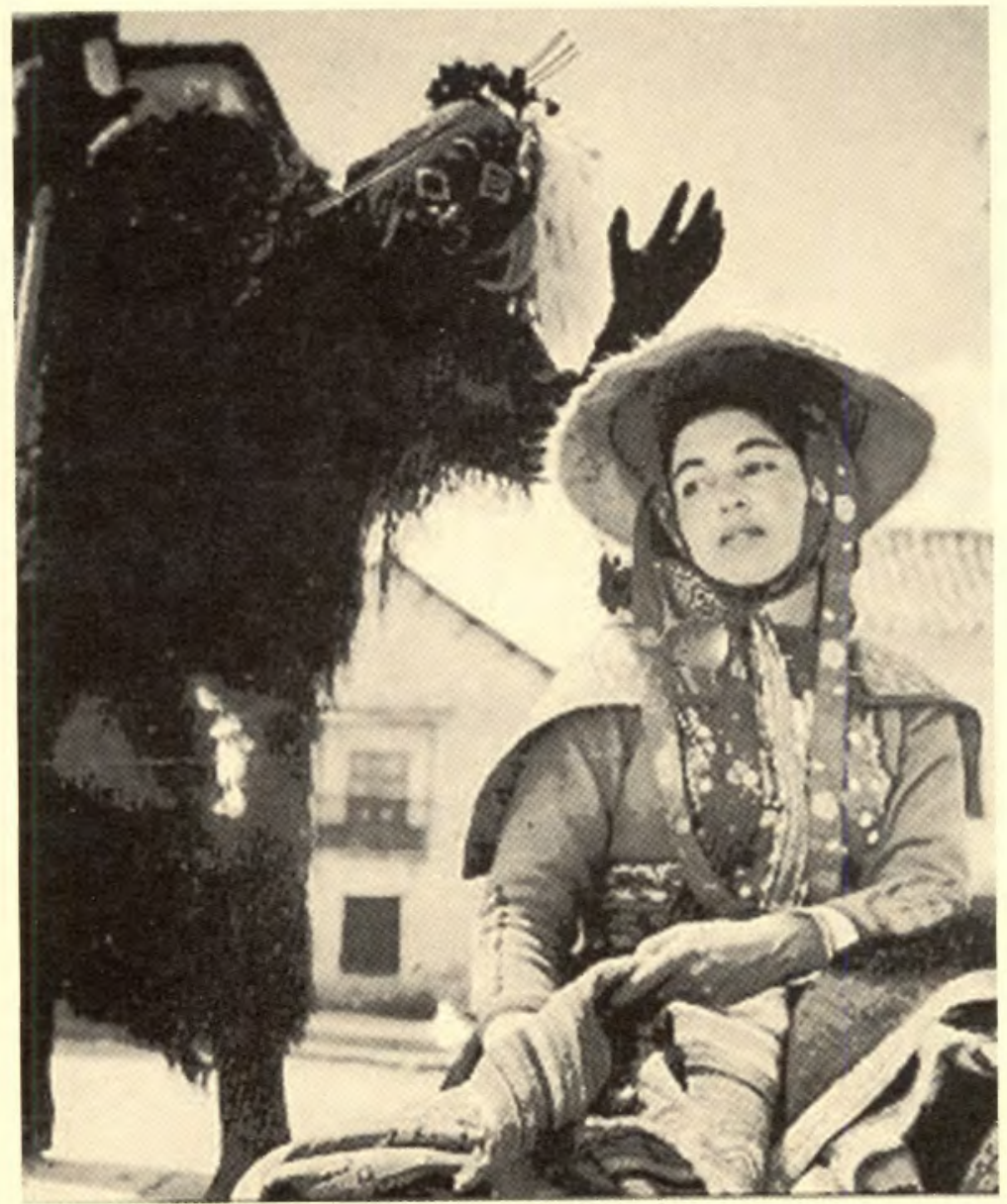

- Imagen fotogrifica de la primera pelicula en quechua "Kratuli".

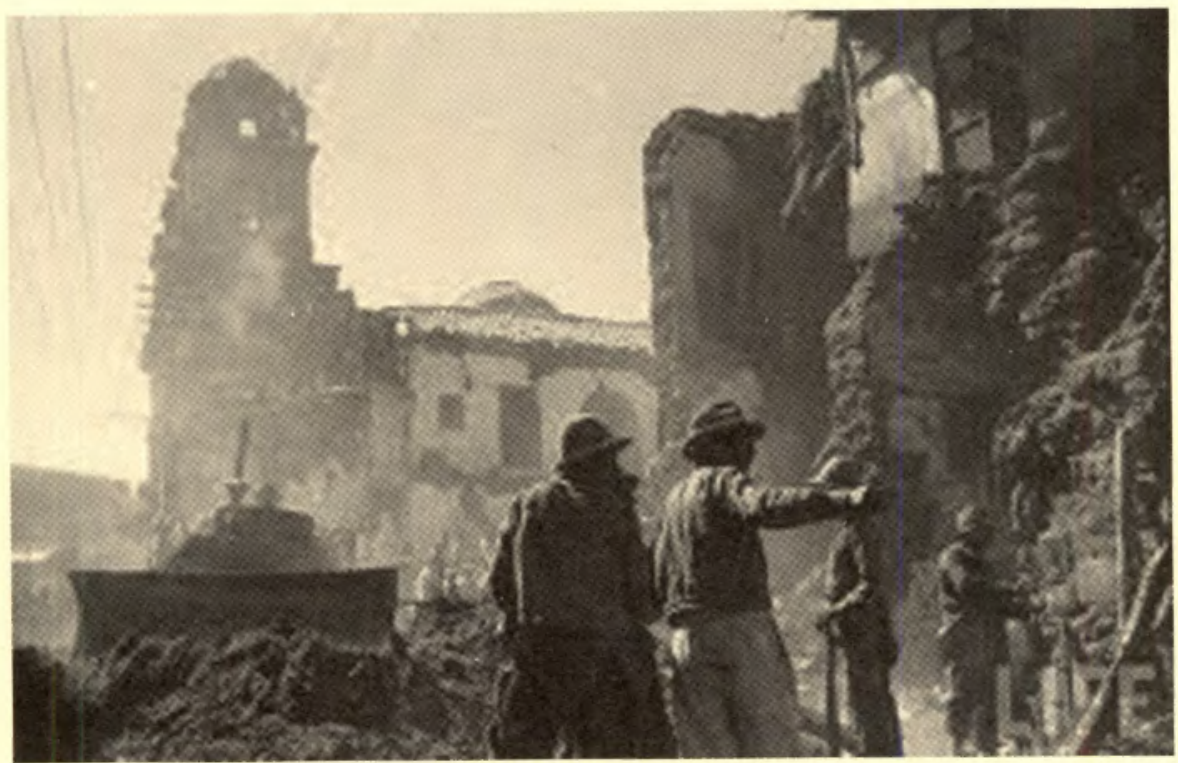

- Imagen fotogrófica del terremoto en Cusco en el año de 7950. 


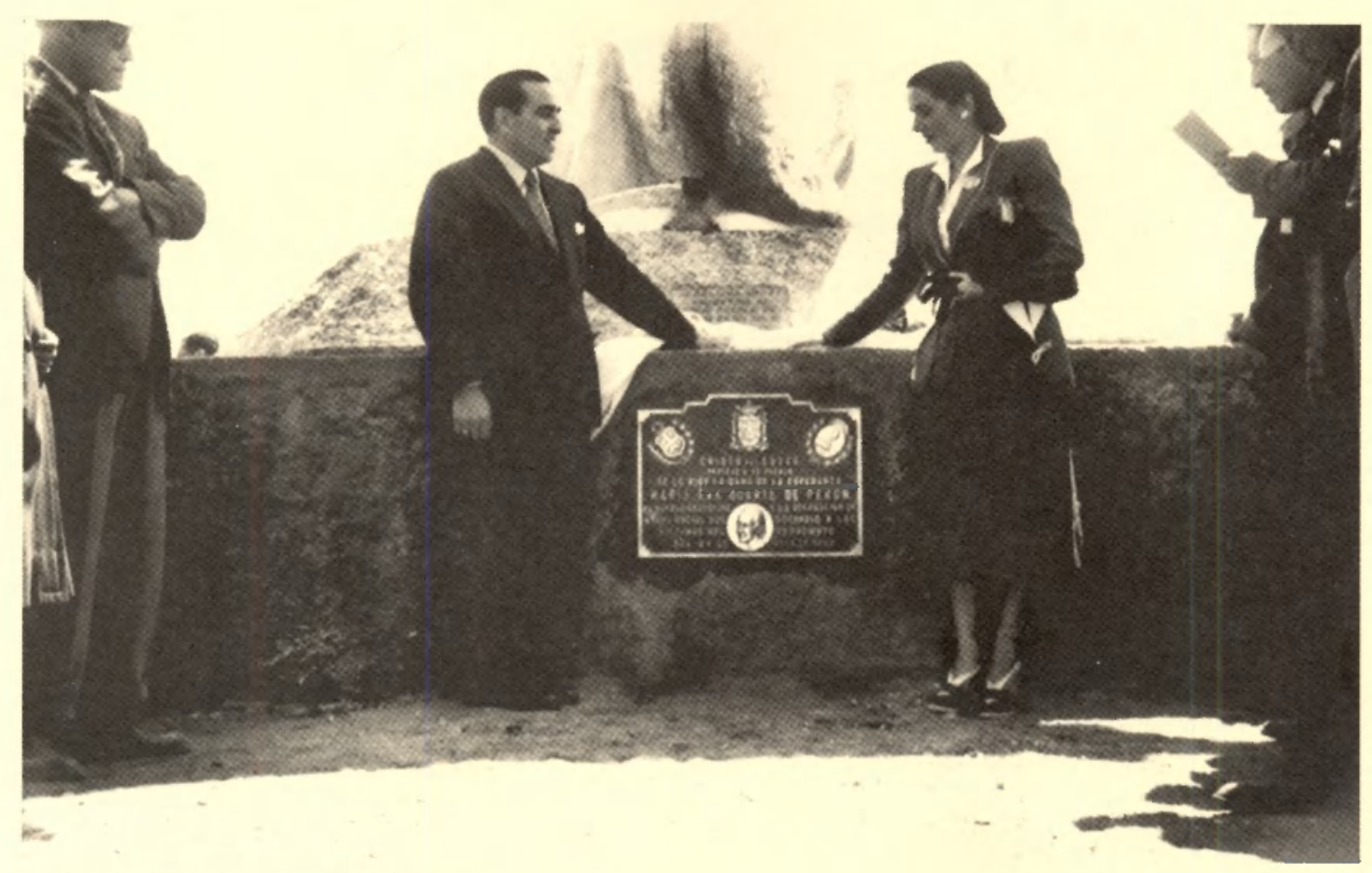

- Eva Perón. Develando una placa, al pre del Cristo Blanco.

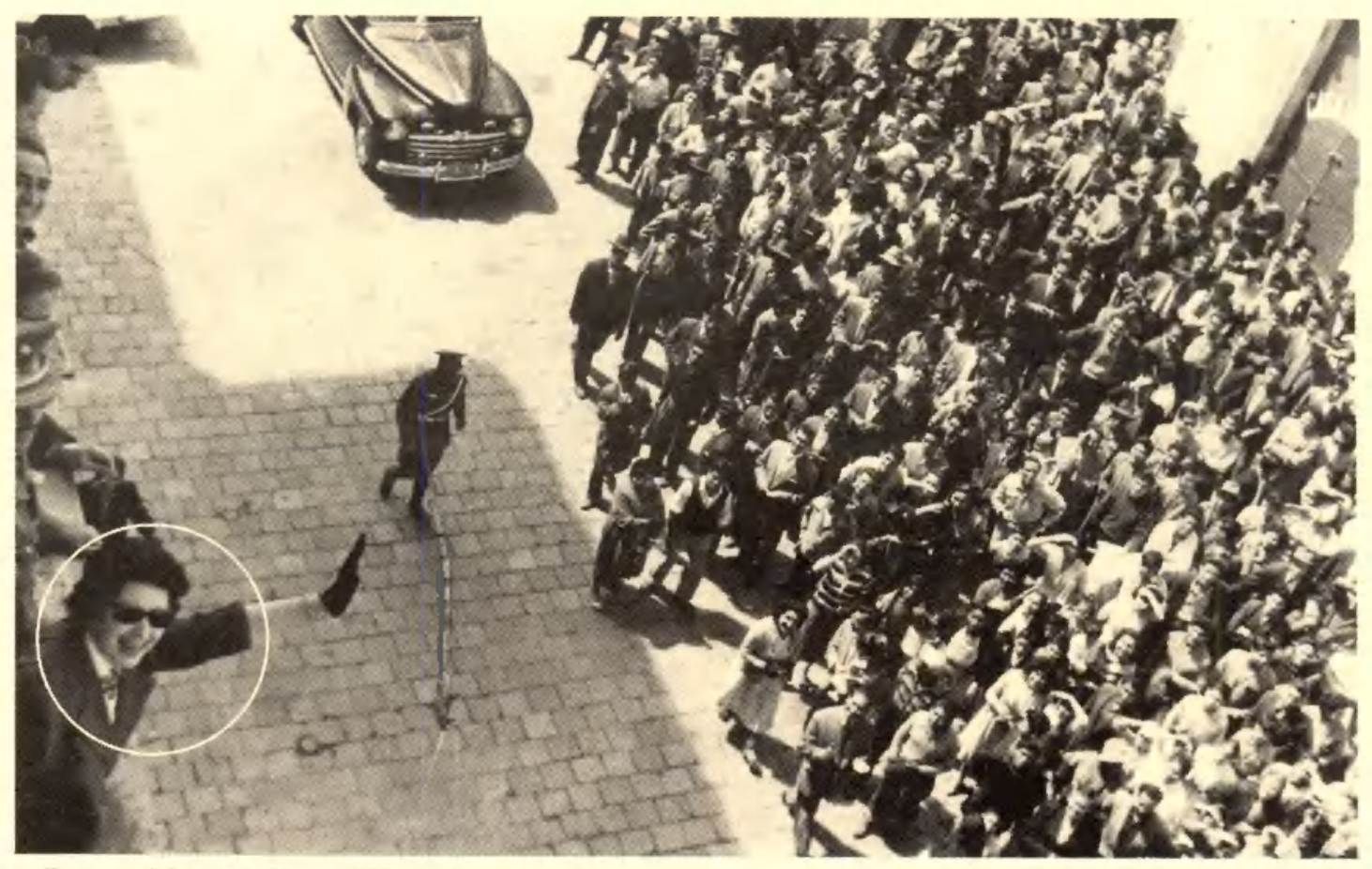

T Eva Duturte de Perón desde el balcoin del Hotel de Turistas 


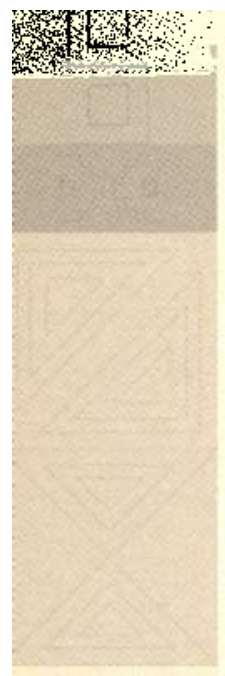

328

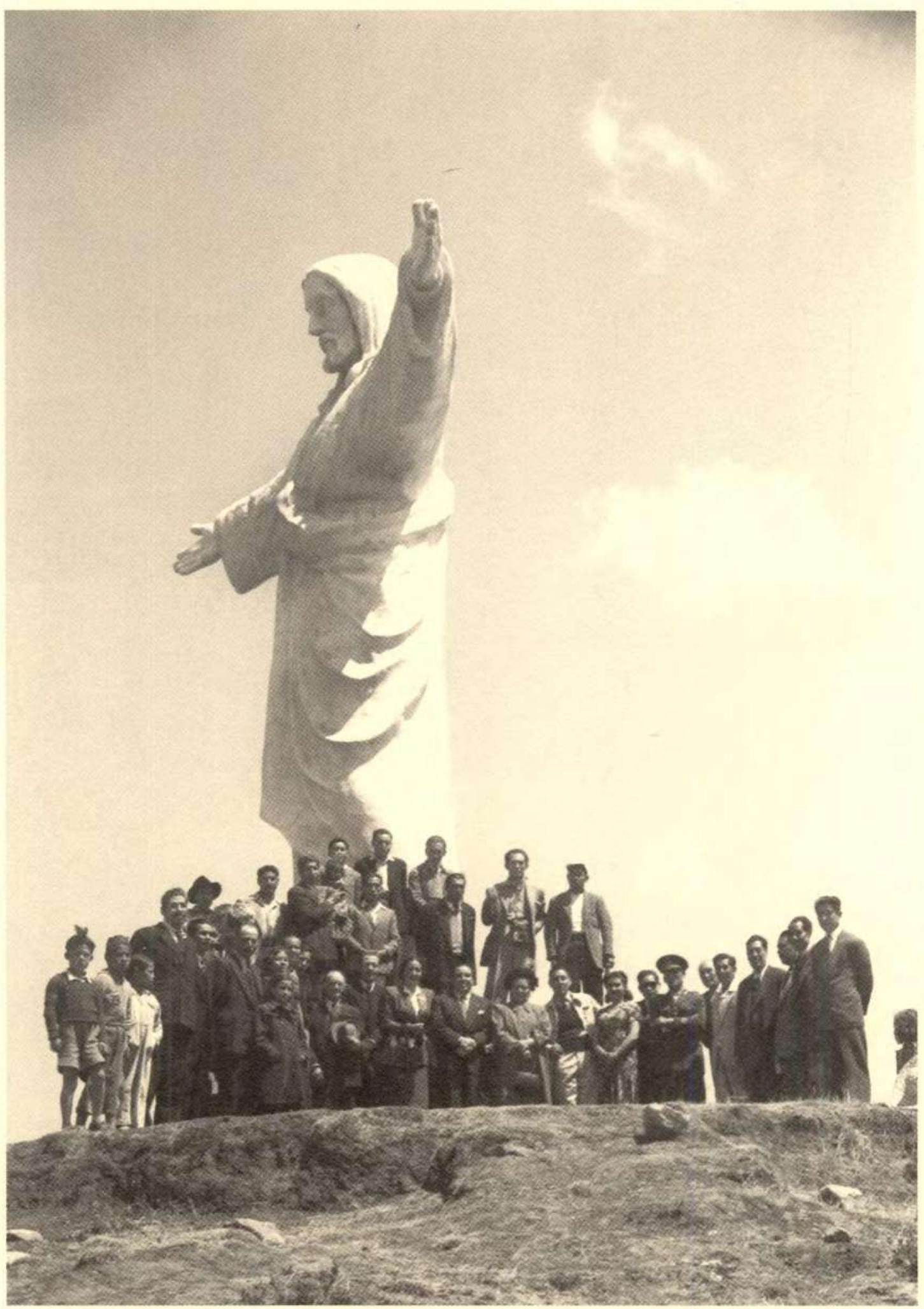

- Eva Perón al pie del Crista Blanco, Cuzza. 